NOTE ON THE OVIPOSITION OF AEDES CALOPUS

\title{
MEIGEN.
}

BY JAMES ZETEK, ANCON, CANAL ZONE.

The writer was taking the adults from a lot of breeding cages and, by accident, one female Aedes calopus escaped. Hardly more than two minutes later he turned his attention to an uncovered cage containing water and larve of Culex coronator $\mathrm{D} \& \mathrm{~K}$, and discovered a mosquito resting on the side of the jar, the tip of its abdomen extending and touching the water, depositing eggs. This occurred at 4.10 p.m., July 2 nd, 1913. The mosquito was A.calopus, and most probably was the one that had escaped a moment before. The cage was covered with gauze.

When the cages were examined at 1.00 a. m., July 5th, very young larvæ of the yellow-fever mosquito were seen in this particular jar. The egg instar is about 60 hours. These larvæ were allowed to mature, and from them emerged $14 \%$ and $18 o^{r}$ adults.

The female which had deposited these eggs had no blood meal, nor any other food than which was present in the air and water. In the original cages of Aedes calopus, copulation was frequently noted, occurring chiefly in the daytime. In the act the male is underneath, clasping the female, the two mosquitos facing each other. The male clasped the female as frequently in flight as when at rest. In one cage, containing one male and many females, the male copulated three successive times during the half hour under observation.

The rapidity with which the mosquito found water suitable for oviposition after its escape is remarkable, and places emphasis upon the cautions to be taken while working with disease-transmitting insects or pests.

\section{PHLEBOTOMUS AND VERRUGA.}

It $w$ suld appear that an addition is likely to be made to the ever-increasing number of cases of the relation of insects to disease. In certain of the valleys of the Pacific slope of the Peruvian Andes, December, 1913 
in South America, an sbscure discase, known as Verruga, has existed for: years. Recently, the possibility of the transmission by sume species of insect, or tick, has been seriously entertained, and we now learn from "Science" (August 15th, 1913) that Mr. Charles H. T. Townsend, who was some time ago especially charged by the Peruvian $G$ rernment with the investigation of the insect transmission of verruga, injected a dog with triturated females of Phlebotomus on July 11th, and on July 17 th secured as a result an unmistakable case of verruga cruption. The gnats used for the injection were secured on the night of July 9th, in Verrugas Canyon, a noted focus of the disease. This is the first experimental transmission of verruga by means of insects, and adds a notable case to the list of insect-bornt discases. The details of the experiment will appear shortly. Further transmission work in laboratory animals will be pursued at once, both by injections and by causing the gnats to bite.

C. G. H

\section{A NEW LEPTODESMID FROM MONTANA. BY RALPH $V$. CHAMBERLIN, CAMBRIDGE, MASS.}

The following description is published separately in order that the name may be available for early use.

Leptodesmus (Chouaphe) elrodi, sp. nov.

Light brown to very deep brown and brownish black, the background sometimes rather obscurely chestnut." Carinal and anal process in darker individuals orange, in paler even more yellowish; the first dorsal plate also paler, yellowish, oblong anterior margin. The metazonites may be be paler caudally.

Head with the median sulcus deep. Vertex moderately finely uneren or coriaceous, bearing several long bristles across vertex and also in clypeal region above those of labial border. Antennæ of moderate length. First or cervical dorsal plate narrower than the second one, anteriorly strongly convex; caudal margin moderately deeply concave mesally; laterally margined. Caudolateral angles with caudal side nearly straight. Dorsum strongly arched; anterolateral corners of plates convexly rounded, in the second to fifth plates a little extended cephalad, but in others more and December, 1913 